\title{
Splicing Genomics Events in Cervical Cancer: Insights for Phenotypic Stratification and Biomarker Potency
}

\author{
Flavia Zita Francies ${ }^{1} \mathbb{D}$, Sheynaz Bassa ${ }^{2}$, Aristotelis Chatziioannou ${ }^{1,3} \mathbb{D}$, Andreas Martin Kaufmann ${ }^{1,4} \mathbb{D}^{\mathbb{D}}$ and \\ Zodwa Dlamini ${ }^{1, *(\mathbb{D})}$
}

1 SAMRC/UP Precision Prevention \& Novel Drug Targets for HIV-Associated Cancers (PPNDTHAC) Extramural Unit, Pan African Cancer Research Institute (PACRI), University of Pretoria, Hatfield 0028, South Africa; flavia.francies@up.ac.za (F.Z.F.); achatzi@bioacademy.gr (A.C.); andreas.kaufmann@charite.de (A.M.K.)

2 Department of Radiation Oncology, Steve Biko Academic Hospital (SBAH), Faculty of Health Sciences, University of Pretoria, Hatfield 0028, South Africa; sheynaz.bassa@up.ac.za

3 Center of Systems Biology, Biomedical Research Foundation Academy of Athens, 4 Soranou Ephessiou str, 11527 Athens, Greece

4 Clinic for Gynaecology, Laboratory for Gynaecologic Tumor Immunology, Institute of Health, Charité-Universitätsmedizin, Freie Universität Berlin, Humboldt-Universität zu Berlin, Augustenburgerplatz 1, 13353 Berlin, Germany

* Correspondence: zodwa.dlamini@up.ac.za; Tel.: +27-76-147-4878

Citation: Francies, F.Z.; Bassa, S.; Chatziioannou, A.; Kaufmann, A.M.; Dlamini, Z. Splicing Genomics Events in Cervical Cancer: Insights for Phenotypic Stratification and Biomarker Potency. Genes 2021, 12, 130. https://doi.org/10.3390/ genes12020130

Received: 19 November 2020 Accepted: 12 January 2021 Published: 20 January 2021

Publisher's Note: MDPI stays neutral with regard to jurisdictional clai$\mathrm{ms}$ in published maps and institutional affiliations.

Copyright: (C) 2021 by the authors. Licensee MDPI, Basel, Switzerland. This article is an open access article distributed under the terms and conditions of the Creative Commons Attribution (CC BY) license (https:// creativecommons.org/licenses/by/ $4.0 /)$.

\begin{abstract}
Gynaecological cancers are attributed to the second most diagnosed cancers in women after breast cancer. On a global scale, cervical cancer is the fourth most common cancer and the most common cancer in developing countries with rapidly increasing mortality rates. Human papillomavirus (HPV) infection is a major contributor to the disease. HPV infections cause prominent cellular changes including alternative splicing to drive malignant transformation. A fundamental characteristic attributed to cancer is the dysregulation of cellular transcription. Alternative splicing is regulated by several splicing factors and molecular changes in these factors lead to cancer mechanisms such as tumour development and progression and drug resistance. The serine/arginine-rich (SR) proteins and heterogeneous ribonucleoproteins (hnRNPs) have prominent roles in modulating alternative splicing. Evidence shows molecular alteration and expression levels in these splicing factors in cervical cancer. Furthermore, aberrant splicing events in cancer-related genes lead to chemoand radioresistance. Identifying clinically relevant modifications in alternative splicing events and splicing variants, in cervical cancer, as potential biomarkers for their role in cancer progression and therapy resistance is scrutinised. This review will focus on the molecular mechanisms underlying the aberrant splicing events in cervical cancer that may serve as potential biomarkers for diagnosis, prognosis, and novel drug targets.
\end{abstract}

Keywords: cervical cancer; alternative splicing; biomarkers; SR proteins; hnRNP; drug resistance

\section{Introduction}

Cervical cancer, also known as cervix uteri cancer, is the fourth most frequently diagnosed cancer globally and the most common malignancy in developing countries [1]. It is the most frequently diagnosed cancer in women in Sub-Saharan Africa (SSA) and the leading cause of cancer-related mortality in this region (Figure 1) [2,3]. An estimated 90\% of cervical cancer-related mortality occurs in low- and middle-income countries [4]. Cervical cancer is predominantly categorised into two main histopathological subtypes-squamous cell carcinoma and adenocarcinoma [5]. Over $75-80 \%$ of all cervical cancers are squamous cell carcinomas [6,7]. Cervical cancer is attributed to a number of risk factors such as sexually transmitted infections including human immunodeficiency virus (HIV) infection, human papillomavirus (HPV) infection, socioeconomic factors, obesity, smoking [8], alcohol consumption [9], unprotected sex and multiple sexual partners, prolonged usage of oral 
contraceptives, and family history of cervical cancer [10]. HPV infection is the major contributor of cervical cancer [11]. HPV is a circular double-stranded DNA virus with capsid proteins with more than 200 subtypes identified and categorised as high and low risk. Of these, about 40 subtypes have an affinity for genital mucosa and are sexually transmitted. The low-risk subtypes are generally associated with genital warts, whereas high risk subtypes cause invasive cervical cancer. The most prominent high-risk HPV genotypes are HPV16 and 18. Persistent infection with these high-risk subtypes contributes to over $99 \%$ of cervical cancers [11]. HPV infections can be prevented by vaccination that confers protection against HPV 6,11, 16, and 18 subtypes, and depending on the vaccine, subtypes $31,33,45,52,58$ can also be prevented. The vaccinations are available as quadrivalent vaccine to target all four subtypes or as bivalent to target only the high-risk subtypes [12] or a combined 9-valent vaccine that targets nine subtypes [13].

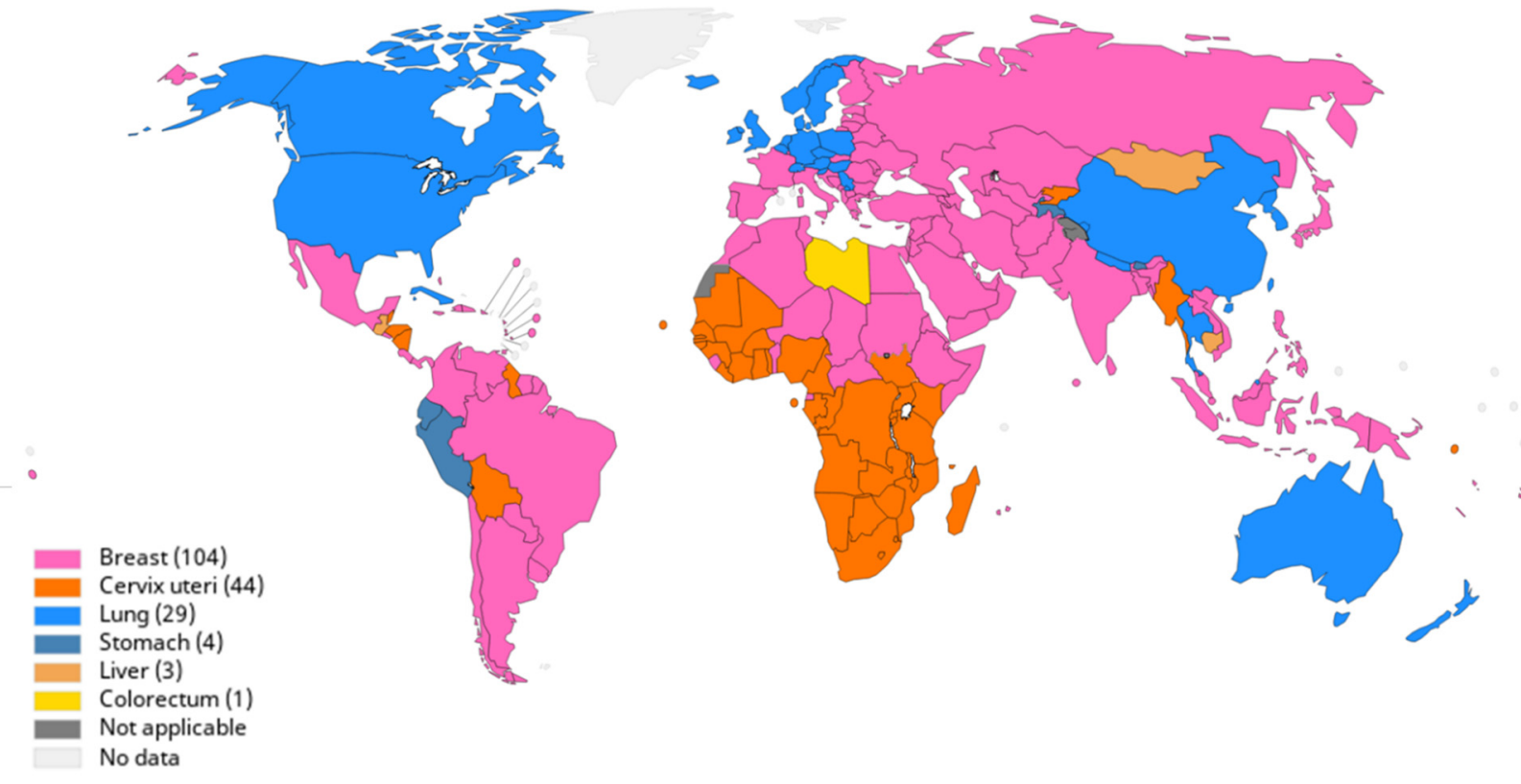

Figure 1. Global cancer mortality. The age standardised rates (ASRs) of various leading cancers worldwide in 2018. Cervical cancer is a major burden in most parts of Africa. Reprinted from [2].

In addition to HPV infections, dysregulated pathways are a fundamental feature in cervical cancer development and progression. For this reason, research in elucidating modifications in cancer-related pathways and alternative splicing is rapidly emerging. Several studies show aberrant alternative splicing and the dysregulation of gene expression in cervical cancer [14-17]. The related molecular signatures offer potential therapeutic targets for novel drug development and improved strategies in cervical cancer management, particularly for advanced disease in developing countries where HPV infections are the major contributor of cervical cancer.

The burden of cervical cancer mortality due to HPV infections is felt prominently in developing nations. Novel therapeutic targets are warranted to address this issue. Moreover, prevention strategies such as HPV vaccinations and pap smears play a significant role in cervical cancer prevention. Modifications in cervical tissue are detected through pap smears and HPV tests, and early diagnosis allows effective management of the disease [1,10]. This review will focus on the molecular mechanisms underlying the aberrant splicing events in cervical cancer that may serve as potential biomarkers for diagnosis and prognosis and as novel drug targets for their therapeutic properties. 


\section{Alternative Splicing and Its Implications in Cervical Cancer}

Alternative splicing is an important process in gene expression and proteome diversity. In this cellular process, introns are spliced to join exons for the production of proteins through several mechanisms (Figure 2). Alternative splicing maintains cellular diversity and regulates the synthesis of multiple protein isoforms from the same gene. These protein isoforms perform several biological functions that are necessary for normal cellular functionality. Alternative splicing is an intricate process that is closely regulated by numerous spliceosome factors that aid in recognition of intron and splice sites such as small nuclear ribonucleoproteins (snRNP) particles and the serine/arginine-rich (SR) proteins [18]. In this process, proteins are synthesised, when introns are spliced and functional exons are joined together. The negative regulation of alternative splicing is achieved by heterogeneous ribonucleoproteins (hnRNPs) that block the intron and exon boundaries [19]. These two protein families-the SR proteins and the hnRNPs-are important trans-acting regulatory factors in splicing and are known to be altered in cervical cancer [20-23]. Enhanced levels of SR lead to splicing induction, whereas splicing is inhibited when hnRNPs are overly expressed. Aberrant alternative splicing, resulting from DNA damage, mutations and expression alterations in splicing factors, miRNA disruptions, and unregulated gene expression, are implicated in cancer mechanisms, such as sustained cell proliferation, apoptotic evasion, tumour suppressor inhibition, angiogenesis, metastasis, and drug resistance $[19,24-26]$. Evidence suggest that aberrant alternative splicing plays an important role in the development of cervical cancer. In cervical cancer, alternative splicing is primarily HPV-mediated. Next generation sequencing (NGS) offers a platform to identify potential disease-causing splice variants and genomic changes in splicing regulatory factors/proteins. Elucidating the functions of these splice variants may provide underlying information on malignant transformation and be beneficial in developing novel strategies for therapeutic interventions [27]. For these reasons, modifications in alternative splicing are becoming a significant biomarker with diagnostic and therapeutic potential.

Alternative splicing of key genes may facilitate the development and progression of cervical malignancy. For instance, the $5^{\prime}$ alternative splicing of the KLHDC7B gene is closely associated with cellular differentiation and tumour size in $67.5 \%$ of squamous cell carcinoma [28]. Similarly, 35\% of exon skipping in the SYCP2 gene was reported in cervical squamous cell carcinoma and associated with invasion and metastases [28]. Evidence also shows the association of cervical cancer and the aberrant alternative splicing of the IL1RAP gene. SRSF10 regulates the splicing of IL1RAP gene and promotes the production of its oncogenic isoform, MIL1RAP. This in turn facilitates the malignant cell evasion of phagocytosis by macrophages. Therefore, aberrant alternative splicing of IL1RAP gene promotes immune evasion and promotes cervical cancer [29]. A recent study by Ouyang et al. (2020) provides evidence that supports the notion that aberrant splicing events are closely associated with cervical cancer development, and the identification of these splicing biomarkers may provide useful prognostic and therapeutic tools [30]. The authors identified 2860 alternative splicing events. Of these, SNRPA and CCDC12 were associated with the tumour suppressor gene, p53, and were identified as hub genes in cervical cancer [30]. These results highlight the need to screen candidate biomarkers associated with cervical cancer that may have a clinical utility in diagnosis, prognosis, and therapy. Biomarkers related to cervical cancer are shown in Table 1. 


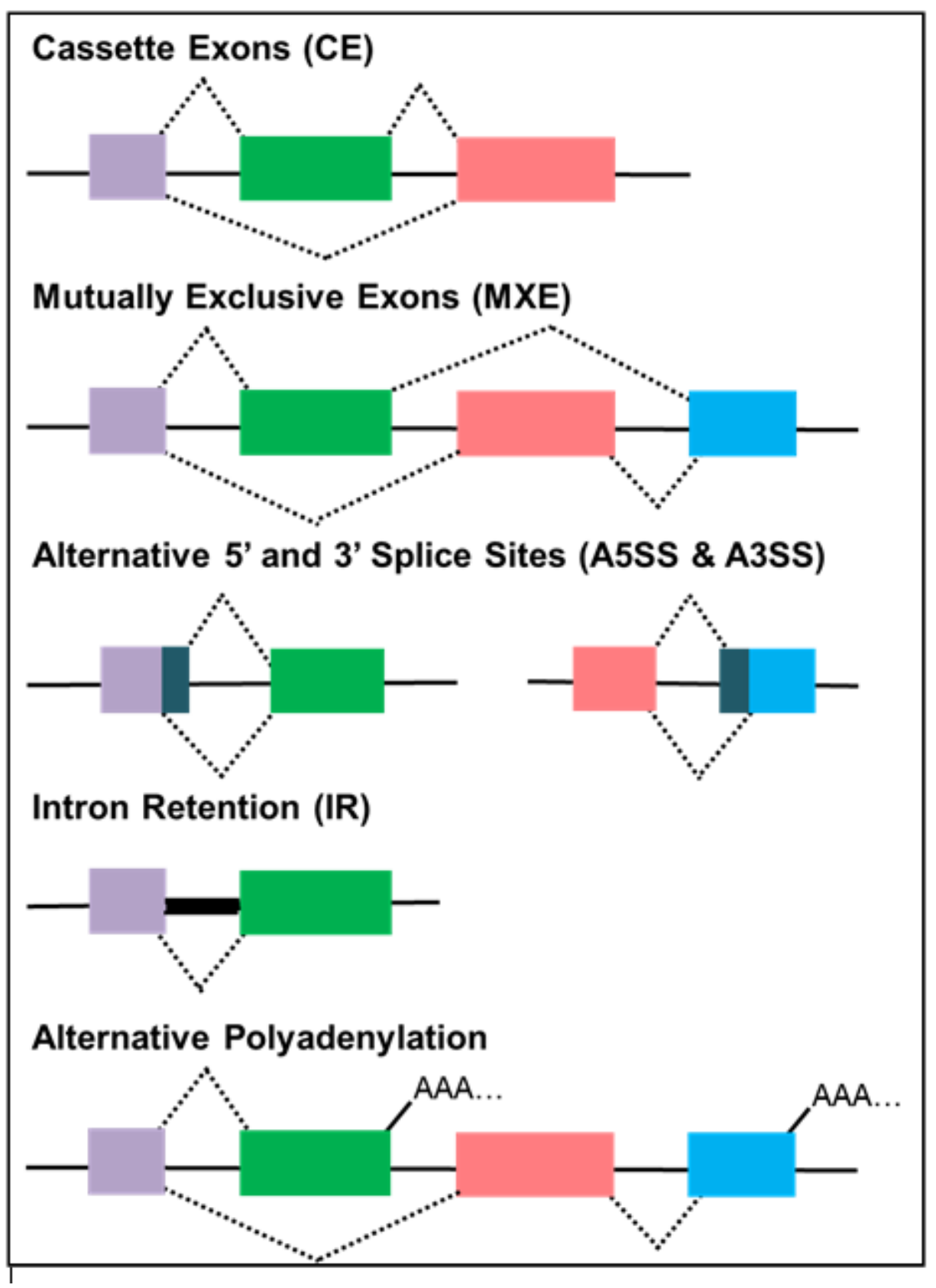

Figure 2. Frequent types of alternative splicing mechanisms. Alternative spliced mRNA produces mature transcripts, namely, cassette exons (CEs), mutually exclusive exons (MXEs), alternative $5^{\prime}$ or $3^{\prime}$ splice sites (A5SS and A3SS), intron retention (IR), and alternative polyadenylation (AP). Coloured boxes: exons; black lines: introns [31-35].

HPV contributes to the development and progression of cervical cancer by disrupting alternative splicing and other cellular functions. The HPV genome is double-stranded and circular; it is divided into three regions, namely, the long control region (LCR) and early and late region. Each region produces proteins that have different functions in the life cycle of HPV and in cancer development [36]. Persistent HPV infection gives rise to malignancy by producing viral proteins necessary to maintain virus replication and oncoproteins. Viral oncoproteins facilitate disease development and progression by abrogating normal cellular functions such as G1 arrest, cell proliferation, apoptosis, DNA repair, and chromosomal instability [37]. In addition, HPV oncoproteins bind to splicing factors and induce aberrant alternative splicing events. Moreover, HPV-related cervical cancer has a number of genes and splicing factors that are significantly upregulated. These 
include genes with vital functions such as immune surveillance, inflammatory response, and tumour suppressors [29,37]. Collectively, the interference of HPV in alternative splicing and cellular function promotes transformation, leading to carcinogenesis.

Table 1. Overview of biomarkers associated with cervical cancer.

\begin{tabular}{|c|c|c|c|c|}
\hline Biomarkers & Biological Function & Modifications in Cervical Cancer & Clinical Utility & Ref. \\
\hline HPV E6 & p53 degradation & Overexpressed in cervical cancer cells & $\begin{array}{l}\text { Screening and } \\
\text { prevention }\end{array}$ & {$[38,39]$} \\
\hline HPV E7 & $\mathrm{pRb}$ degradation & Overexpressed in cervical cancer cells & $\begin{array}{l}\text { Screening and } \\
\text { prevention }\end{array}$ & {$[38,39]$} \\
\hline AURKA & Genomic stability & $\begin{array}{l}\text { Overexpressed in precancerous and } \\
\text { cancerous cervical cells }\end{array}$ & Early detection & [40-42] \\
\hline DTL & Checkpoint regulation & Overexpressed in cervical cancer cells & Early detection & {$[41]$} \\
\hline HMGB3 & $\begin{array}{l}\text { Maintain balance in } \\
\text { stem cell population }\end{array}$ & Overexpressed in cervical cancer cells & Early detection & [41] \\
\hline KIF2C & Cell proliferation & Overexpressed in cervical cancer cells & Early detection & [41] \\
\hline NEK2 & $\begin{array}{l}\text { Mitotic and cell } \\
\text { cycle regulation }\end{array}$ & Overexpressed in cervical cancer cells & Early detection & [41] \\
\hline RFC4 & DNA replication & Overexpressed in cervical cancer cells & Early detection & {$[41]$} \\
\hline p16ink4a & Tumour suppressor & $\begin{array}{l}\text { Overexpressed in precancerous and } \\
\text { cancerous cervical cells }\end{array}$ & $\begin{array}{l}\text { Screening and } \\
\text { diagnosis }\end{array}$ & [43-45] \\
\hline Ki-67 & Cell proliferation & $\begin{array}{l}\text { Increased expression in proliferating } \\
\text { epithelial cervical lesions }\end{array}$ & $\begin{array}{l}\text { Screening and } \\
\text { diagnosis }\end{array}$ & {$[43,46]$} \\
\hline MCM2/TOP2A & DNA synthesis & Overexpressed in cervical dysplasia & Diagnosis & {$[38,47]$} \\
\hline MSI1 & RNA binding protein & Overexpressed in cervical cancer cells & $\begin{array}{l}\text { Diagnostic and } \\
\text { therapeutic }\end{array}$ & [48-51] \\
\hline $\begin{array}{l}\text { miR-21, miR-127 and } \\
\text { miR-199a }\end{array}$ & - & $\begin{array}{l}\text { Increased expression in cervical } \\
\text { cancer cells }\end{array}$ & Prognosis & [39] \\
\hline $\begin{array}{l}\text { miR-143, miR214, } \\
\text { miR-218 and miR-34a }\end{array}$ & - & $\begin{array}{l}\text { Decreased expression in cervical } \\
\text { cancer cells }\end{array}$ & Prognosis & [39] \\
\hline ALDH1 & $\begin{array}{l}\text { Cellular differentiation } \\
\text { and proliferation }\end{array}$ & Overexpressed in cervical cancer cells & $\begin{array}{l}\text { Prognosis and } \\
\text { predictive }\end{array}$ & {$[48,51,52]$} \\
\hline EGFR & $\begin{array}{l}\text { Transmembrane } \\
\text { protein }\end{array}$ & Overexpressed in cervical cancer cells & $\begin{array}{l}\text { Prognosis and } \\
\text { predictive }\end{array}$ & {$[53,54]$} \\
\hline Oct $3 / 4$ & Transcription factor & Overexpressed in cervical cancer cells & $\begin{array}{l}\text { Prognosis and } \\
\text { predictive }\end{array}$ & {$[48,52,55]$} \\
\hline Sox2 & Transcription factor & Overexpressed in cervical cancer cells & $\begin{array}{l}\text { Prognosis and } \\
\text { predictive }\end{array}$ & {$[51,55]$} \\
\hline CD49f & Stem cell marker & Overexpressed in cervical cancer cells & $\begin{array}{l}\text { Prognosis and } \\
\text { predictive }\end{array}$ & {$[48,51,56]$} \\
\hline CD133 & Cell surface antigen & Overexpressed in cervical cancer cells & $\begin{array}{l}\text { Prognosis and } \\
\text { predictive }\end{array}$ & {$[48,57]$} \\
\hline CD44 & $\begin{array}{l}\text { Cellular differentiation } \\
\text { and proliferation }\end{array}$ & Overexpressed in cervical cancer cells & Predictive & {$[48,58]$} \\
\hline KAT2B & $\begin{array}{l}\text { Mitotic and cell cycle } \\
\text { regulation }\end{array}$ & Downregulated in cervical cancer cells & Predictive & [59] \\
\hline
\end{tabular}




\subsection{HPV-Mediated Disruptions in Serine/Arginine-Rich (SR) Proteins}

The spliceosome is crucial in regulating alternative splicing. In addition, other regulatory factors that are short DNA sequences, known as exonic splicing enhancers (ESEs), exonic splicing silencers (ESSs), intronic splicing enhancers (ISEs), and intronic splicing silencers (ISSs), ensure accurate splicing [60]. The splicing regulators have either a positive or negative effect on alternative splicing. ESE and ISE are cis-acting elements that are capable of binding the SR protein family to facilitate recognition of exons and initiate assembly of the spliceosome prior to alternative splicing (Figure 3) [61]. SR proteins are also known as SR splicing factors (SRSF) with SRSF1-12 as the major proteins in this family that have been identified as splicing regulators [62]. SR proteins have other vital cellular functions that are hallmarks of cancer, namely, cell cycle regulation, apoptosis, genome stability, cell adhesion and metastasis [27,63], and angiogenesis [64].

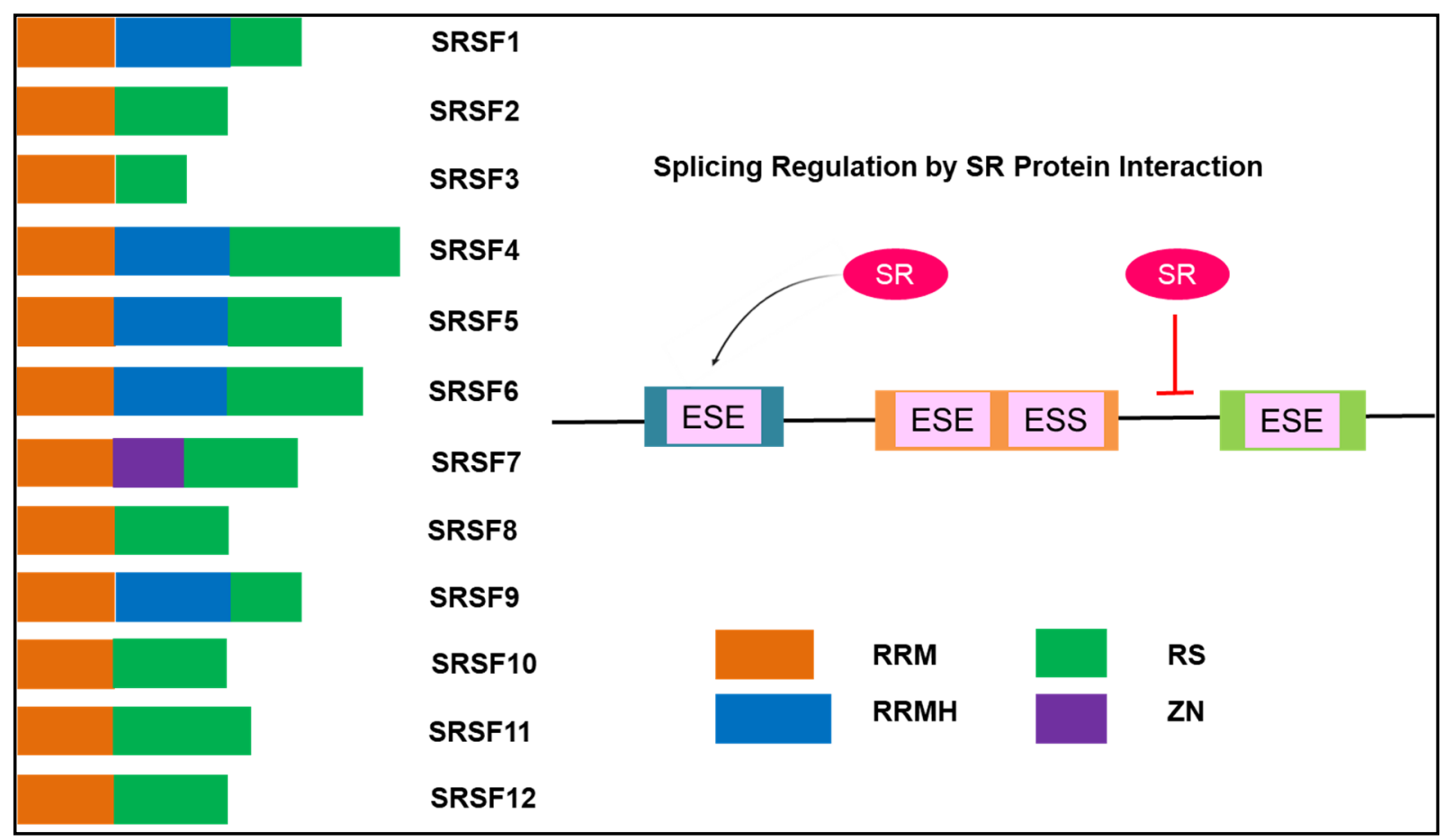

Figure 3. Alternative splicing regulation by SR binding. The domain structure of the 12 serine-rich (SR) proteins indicating the RRM (RNA recognition motif), RRMH (RRM homology), RS (arginine/serine-rich domain), and Zn (Zink knuckle). SR proteins bind to exonic splicing enhancers (ESEs), facilitating splice site recognition and stimulating the activation of splicing. In comparison, splicing is inhibited by the binding of the SR to introns [64-66].

The SRSF regulates splicing by determining the cycle of phosphorylation of SR proteins. CDC-like kinases (Clks), SR protein-specific kinases (SRPKs), and Topoisomerase 1 modulate the activation of SRSFs through a cycle of phosphorylation and dephosphorylation [18]. In the event of dephosphorylation, SRSFs begin to accumulate in the cytoplasm [64]. In comparison, phosphorylated SRSFs are transported to the nucleus to stimulate splicing. The SRPKs are capable of splicing regulation by the binding action to Clks in the nucleus and the cytoplasm [21]. In addition to splicing regulation, evidence suggests that SRPKs are able to modulate viral genomic material such as the HPV [18,21,31]. Evidence shows the binding of HPV E4 protein to SRPK1 [18]. This binding action impedes activation of SR protein by inhibiting the phosphorylation of SRSF1, SRSF3, SRSF4, and SRSF7 and impedes the pre-mRNA processing (Figure 4) [67]. This leads to aberrant cellular splicing that results in oncoprotein production and cervical cancer [18]. 


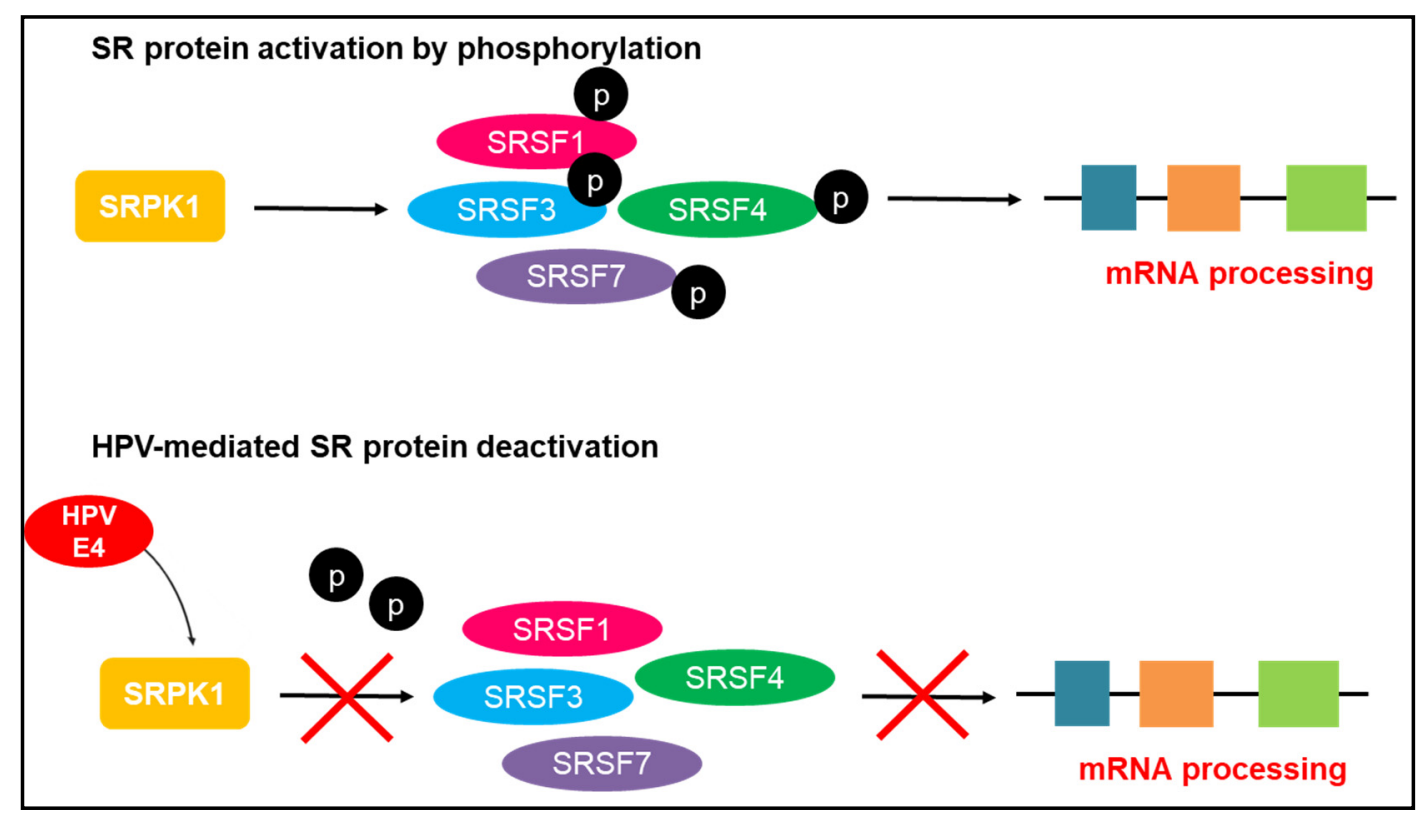

Figure 4. Human papillomavirus (HPV)-mediated disruption of accurate mRNA processing. The binding of HPV E4 protein leads to the deactivation of SR splicing factors (SRSFs) 1,3,4, and 7 by the loss of phosphorylation. This concomitantly inhibits pre-mRNA splicing, leading to inaccurate splicing and production of oncoproteins that give rise to malignancy [18,67]. SRPK: SR protein-specific kinase.

Evidence sheds light on the oncogenic role of SRSF1 [68] and a recent report shows its involvement in cervical malignancy [21]. Mole et al. (2020) showed enhanced levels of SRSF1 in cervical cancer cells. The authors showed the trans-activation of the SRSF1 gene promoter by the high-risk HPV16 E2 protein, with differing levels in the nucleus and cytoplasm [21]. Modifications of SRSF1 abrogate alternative splicing and facilitate genomic instability and cervical malignancy. Henceforth, the results suggest that the increased cytoplasmic levels of SRSF1 are associated with early tumour progression [21]. Other evidence shows the interaction of SRSF1 binding to long non-coding RNAs (lnRNA) to regulate expression levels of keratin 17. Cervical cancer cells display enhanced levels of keratin 17. Dong et al. (2019) showed the interplay between SRSF1 and lnRNA to modulate expression of keratin 17 through alternative splicing in cervical cancer [22]. In addition to SRSF1, SRSF3 regulates the expression of a number of genes and the overexpression of SRSF3 has been shown to modulate cell proliferation by inducing G2/M cell cycle arrest and apoptosis [69,70]. SRSF3 induces production of interleukin enhancer binding factor 3 (ILF3) isoform 1 and 2 through aberrant alternative splicing. These isoforms are involved in malignant transformation [71]. Furthermore, SRSF3 regulates expression of p300, a tumour suppressor, and induces cell proliferation [70]. In HPV-infected cervical cells, SRSF3 plays a significant part in the $\mathrm{E}^{*}$ splicing that is vital for E7 production [72] and in E1^E4 for viral replication [73]. Silencing SRSF3 in HPV-infected cells shows downregulation of viral E6 and E7 [72] and suppresses the E1^E4 splicing [73]. These results highlight the oncogenic potential of SRSF3 that may lead to cellular transformation and may contribute to cervical cancer [69].

DNA damage response plays a vital role in maintaining genomic stability and preventing carcinogenesis. Several important genes are involved in DNA damage pathways such as RAD51, ATM, p53, and ERCC1 [74]. Detecting modifications in DNA repair genes could be beneficial as biomarkers for diagnosis, prognosis, and targets for therapy. For instance, evidence shows the upregulated RAD51 mRNA levels in cervical cancer, which are associated with poor prognosis [75]. In addition to somatic mutations, HPV induces DNA damage in cervical cancer cells [76] and the resulting DNA damage response gene expression serves as prognostic biomarkers [77]. New evidence shows the association 
between SRSF6 and DNA damage genes. Yang et al. (2020) evaluated the function of SRSF6 in cervical cancer cells and showed that overexpressed SRSF6 influenced the alternative splicing of DNA damage genes [78]. SRSF6-induced aberrant alternative splicing of DNA damage genes is associated with the hallmarks of cancer such as cell proliferation, tumour progression, and apoptosis [78]. Elucidating the functional impact of SRSF6 in alternative splicing of DNA damage genes could offer a target for cervical cancer therapy.

\subsection{HPV-Mediated Disruptions in Heterogeneous Ribonucleoproteins (hnRNPs)}

The ESS and ISS act as negative regulators to repress alternative splicing and bind to the hnRNP family of proteins. Similar to SR proteins, the hnRNPs can either positively or negatively regulate splicing by binding to ESS and ISS, negatively prompting exon definition (Figure 5). There are currently at least 20 hnRNPs identified with several important cellular functions including alternative splicing [31]. Loss of regulation in hnRNPs leads to modified gene expression of tumour suppressors and other cancer-related genes [27,79]. Henceforth, hnRNPs are implicated in malignant transformation and could be scrutinised as potential cancer-related biomarkers.

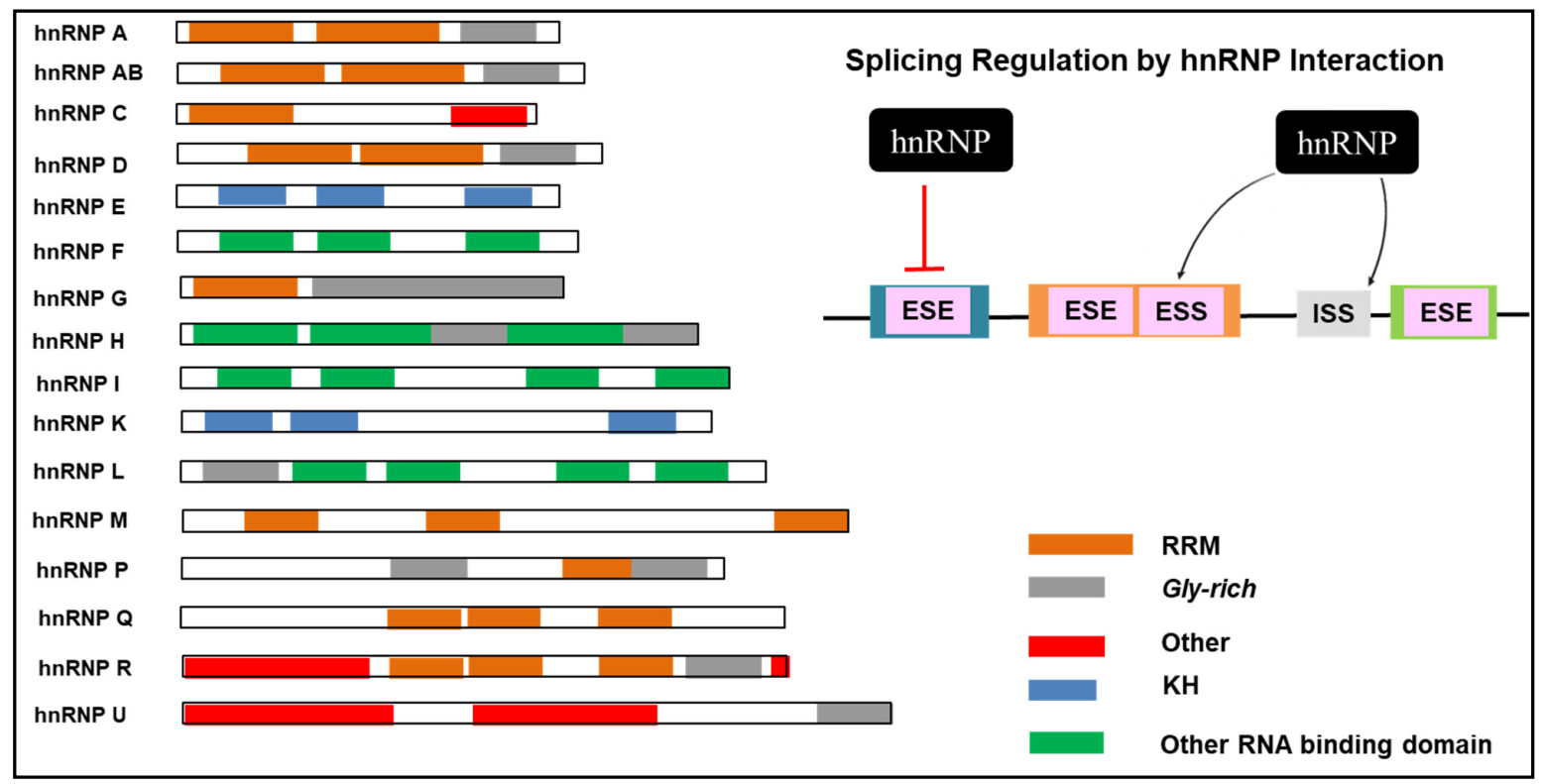

Figure 5. Alternative splicing regulation and the structural domains of hnRNP family. The domain structure of the hnRNP showing the RRM (RNA recognition motif), $\mathrm{KH}$ (K homology domain), and other RNA binding domain that is structurally different from RRM. hnRNP negatively regulates this process by binding to either exonic splicing silencers (ESSs) or intronic splicing silencers (ISSs). In addition, hnRNP blocks the activity of exonic splicing enhancers (ESEs) by binding to it $[34,65,80]$.

Alternative splicing events are frequent in cervical cancer and are significantly associated with diagnosis and prognosis. Major splicing factors promote cervical malignancy by facilitating the production of HPV mRNAs and oncoproteins required. In addition, cellular oncogenic protein production is favoured to enhance the development of cervical cancer (Table 2). Cervical cancer cells have elevated expression of hnRNPs. For instance, hnRNPA1 is highly expressed in cervical cancer cells and can disrupt cancer-related genes. The alternative splicing of pyruvate kinase mRNA is induced by hnRNPA1 and favours aerobic glycolysis, resulting in uncontrolled cell proliferation. In the event where hnRNPA1 is downregulated, cancer-specific apoptosis is induced. hnRNPA1 is thus a good biomarker for cervical cancer diagnosis [23]. Another recent study investigated prognostic biomarkers of alternative splicing in cervical cancer and revealed hnRNPA1, ubiquitin C, and RNA polymerase II subunit L as effective prognostic biomarkers [81]. As a crucial component in alternative splicing, scrutinising the aberrant splicing induced by hnRNPA1 in cervical 
cancer is critical. Additionally, during the HPV infection-related differentiation of cervical epithelial cells, hnRNPA1 is further upregulated and enables oncoviral protein transcription. Deleterious mutations in hnRNPA1 have been identified and may alter expression levels contributing to aberrant alternative splicing, mRNA processing, and translation [82].

Table 2. The role of major splicing factors, the human papillomavirus (HPV) binding region, and function of transcripts in cancer progression.

\begin{tabular}{cccc}
\hline Splicing Factor & HPV Binding Region & HPV16 mRNA & Cancer Promoting Function \\
\hline SRSF1 & E4 & Production of E6/E7 mRNA & Apoptotic regulation \\
\hline SRSF3 & E4 & Production of E6/E7 mRNA & Increased cell proliferation \\
\hline SRSF9 & E4 & Production of late mRNAs & $\begin{array}{c}\text { Increased cell proliferation and } \\
\text { suppressed apoptosis }\end{array}$ \\
\hline hnRNPA1 & L1 & Production of the isoform E6 ${ }^{*} /$ E7 & Apoptotic regulation \\
\hline hnRNPA2/B1 & E4 & Production of the isoform E6 ${ }^{*}$ I/E7 & Apoptotic regulation \\
\hline hnRNPC & Early $3^{\prime}$-UTR & Production of L1 mRNA & - \\
\hline hnRNPD & E4 & Production of late mRNAs & - \\
\hline hnRNPE1/E2 & L2 & Inhibition of L2 mRNA & - \\
\hline hnRNPG & E4 & Production of late mRNAs & - \\
\hline hnRNPH & L2 & Inhibition of late mRNAs & Cell cycle regulation \\
\hline hnRNPI & Early $3^{\prime}$-UTR & Inhibition of late mRNAs & -
\end{tabular}

UTR: Untranslated region. Reviewed in [31].

Prolonged HPV infections influence cellular and viral alternative splicing to enhance viral oncogene production, leading to malignant transformation of the cervix. Malignant transformation is initiated and sustained by the high-risk HPV16 E6 and E7 proteins that interact with tumour suppressor genes $\mathrm{p} 53$ and retinoblastoma protein $(\mathrm{pRb})$, respectively. The interaction of E6 with p53 results in apoptosis, whereas E7 steers cell proliferation by interacting with $\mathrm{pRb}[83,84]$. Moreover, E6 and E7 are essential in viral replication [85]. Zheng et al. (2020) showed splicing regulation of E6 and E7 by cellular hnRNPA1 and hnRNPA2 [20]. This study revealed the direct interaction of hnRNPA1 and hnRNPA2 with high-risk HPV16 splice site SA742 and SA409. The authors showed the inhibition of SA409 when hnRNPA1 is overexpressed and favouring viral E6 mRNA production. In comparison, when hnRNPA2 is upregulated, the viral E6Ê7, E1, and E4 mRNA transcripts are favoured [20]. Adequate amounts of both E6 and E7 transcripts are required for the development of cervix carcinoma. Furthermore, evidence also shows that HPV interacts with hnRNPA1 and the silencing of hnRNPA1 suppresses E6 intron retention [73]. Hence, targeting hnRNPA1 and hnRNPA2 to modulate viral E6 and E7 mRNA transcripts may provide novel therapeutic strategies.

\section{Alternative Splicing and Therapy Resistance}

Drug resistance is a considerable hurdle in cancer treatment and management. Aberrant alternative splicing events are a common theme in cancer drug resistance and, therefore, strategies targeted to silence variants that promote drug resistance are highly warranted. Aberrant splice variants can promote resistance to chemotherapy and radiotherapy [24,86-88] by mechanisms that include apoptotic regulation, modified drug metabolism, response to DNA damage, and regulation of cell proliferation (Figure 6) [89]. Radiotherapy is an important therapeutic modality for the management of advanced cervical cancer and radioresistance may be detrimental. In cervical cancer, a splice variant of nucleophosmin 
(NPM) protein resulting from alternative splicing causes radioresistance [86]. NPM functions in mRNA processing, genome stability, and apoptotic regulation [90]. Enhanced expression of the NPM2 variant is correlated with a radio-protective function. Evidence shows that silencing the NPM2 splice variant decreases radioresistance in cervical cancer cells in a dose-dependent manner [86]. Similarly, enhanced levels of $\Delta N p 73$, a splice variant of $p 73$, have anti-apoptotic functions and display radioresistance in cervical cancer cells [91]. p73 (i) is a p53 homologue that expresses the oncogenic isoform $\Delta \mathrm{Np} 73$ [92]; (ii) functions in DNA damage repair, cell cycle regulation, and apoptosis with p73 polymorphism closely associated with cervical cancer [93]; and (iii) is a prognostic biomarker for cervical cancer [94]. Cervical cancer cells exposed to high-LET radiation degrade $\Delta \mathrm{Np} 73$ to exhibit enhanced apoptosis and cell cycle arrest at the G2/M phase when compared with low-LET radiation [91]. In addition, $\triangle \mathrm{Np73}$ promotes malignant transformation by interacting with RAS and inducing drug resistance to chemotherapy and radiotherapy [87]. Furthermore, the HPV oncoprotein, E6, suppresses the activity of p53 expression and alters sensitivity to radiotherapy. The overexpression of the splice variant, $p 73 \alpha$, in $p 53$ deficient cervical cancer cells, enhances sensitivity to radiotherapy [95]. These results highlight the importance of targeting aberrant splice variants to reverse radioresistance in cervical cancer, which is significantly relevant in treating advanced metastatic disease.

Cervical cancer is often managed with chemotherapy and radiotherapy concurrently. An estimated $50 \%$ of patients do not attain a complete response to therapy due to resistance. Alterations in molecular pathways that promote drug resistance are potential drug targets to counteract resistance [96]. For instance, the CRK-like (CRKL) adapter protein is overexpressed in approximately $50 \%$ of cervical cancers. Moreover, evidence shows that CRKL significantly regulates alternative splicing of pre-mRNA in cancer-related genes in cervical carcinoma to promote malignant transformation, metastases, and chemoresistance by binding to BCR-ABL and activating the Src and Akt signally pathway through phosphorylation $[97,98]$. Additionally, recent evidence shows the role of AKT3 mRNA in inducing cisplatin resistance [99]. By blocking the activity of Src and Akt through pharmacological inhibitors such as dasatinib [97] and fucoxanthin [100], respectively, aberrant splicing events that facilitate chemoresistance in cervical cancer can be reversed and promote a complete therapy response in advanced metastatic disease.

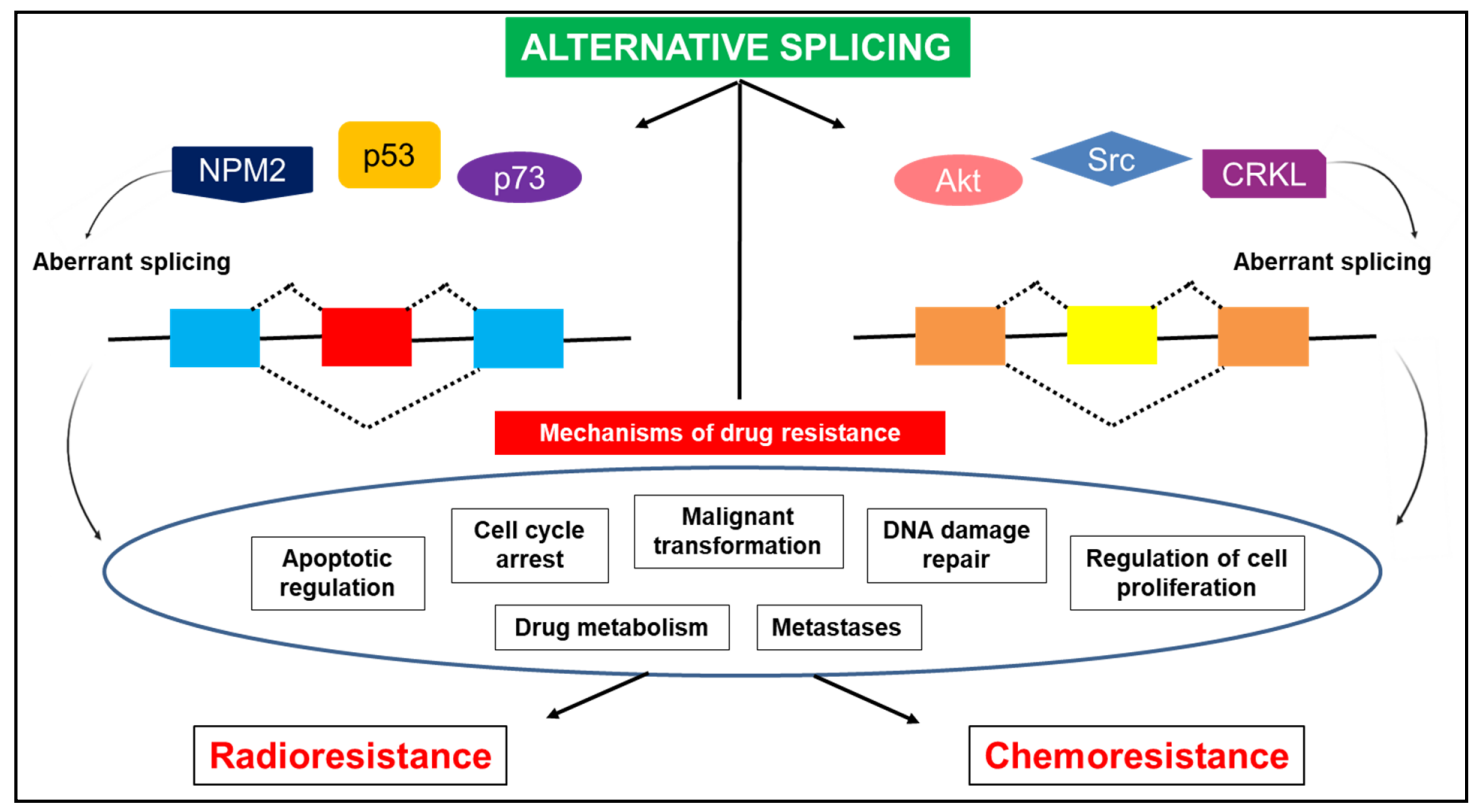

Figure 6. Alternative splicing-induced drug resistance. Aberrant splicing events of vital genes in cervical cancer cells promote drug resistance through several mechanisms by regulating apoptosis, cell cycle arrest, cell proliferation, and DNA damage response. In addition, splice variants may also alter drug targets that effect drug metabolism and lead to chemoresistance and alter the sensitivity to radiotherapy [86,87,89,95,97-99]. 


\section{Clinical Utility of Biomarkers in Cervical Cancer}

Altered expression of splicing regulators, deleterious mutations in splicing regulators and splicing regulatory sequences, and suppressed activity of splicing regulators can cause aberrant alternative splicing, which may result in tumourigenesis and therapy resistance (Figure 7). However, alternative splicing biomarkers have been studied extensively as potential targets of novel therapy [24,27]. The current diagnostic and prognostic indicators of cervical cancer are largely clinicopathology and HPV screening intensive. With the introduction of NGS, large-scale RNA sequencing can be clinically utilised to identify tissue-specific molecular biomarkers. Subsequent to the identification of onco-biomarkers, functional biological assays are imperative to characterise the properties of effective and clinically significant biomarkers for novel clinical utility in diagnosis, prognosis, and therapeutic interventions [27].

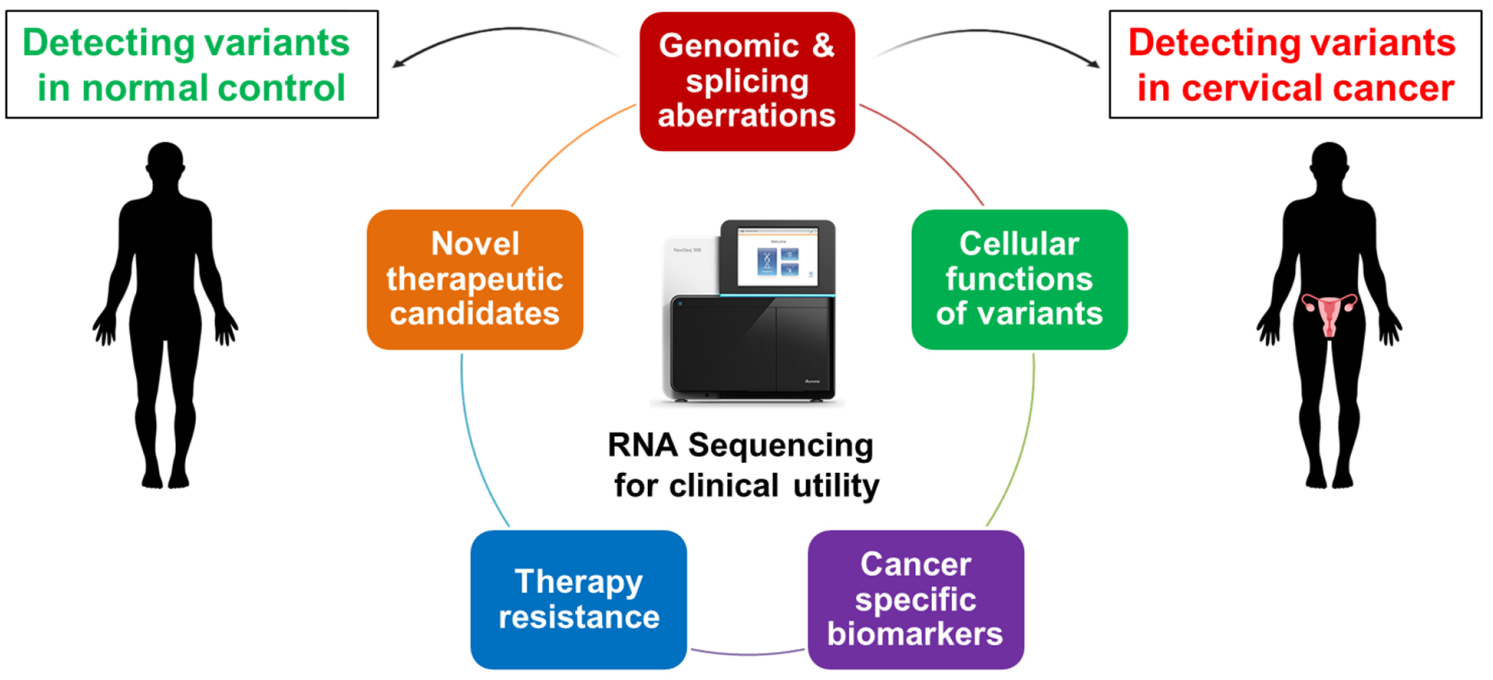

Figure 7. Overview of clinical biomarker identification. Aberrant alternative splice variants are often expressed in significantly higher levels compared with normal splice variants that can be identified through next generation sequencing (NGS). These aberrations can contribute to the development of tumourigenesis, therapy resistance, and poor prognosis. The effects of aberrant alternative splicing can be addressed by identifying cervical cancer-specific genomic and splicing aberrations that are clinically relevant for novel diagnostic, prognostic, and therapeutic purposes [24,81].

Reversing aberrant alternative splicing or silencing oncogenic variants could offer therapeutic strategies in managing cervical cancer. Pharmacological agents are frequently evaluated for their splicing inhibitory or silencing effects in cancer cells. The current alternative splicing modulators studied are small molecule splicing inhibitors, transsplicing, antisense oligonucleotides, and gene therapy. These modulators can regulate alternative splicing by controlling the functioning of spliceosomal activity [27]. For instance, caffeine suppresses the expression of SRSF2/3 and p $53 \alpha$, while upregulating the alternative spliced variant of p $53 \beta$. Caffeine regulates cellular functions such as cell cycle arrest, DNA damage, and apoptosis by modulating the SRSF3 [101,102]. Cervical cancer cells treated with caffeine showed tumour suppression through the modulation of splicing factors. In addition, the recent evidence shows that pladienolide B inhibits the splicing factor SF3b1, which is a subunit of the spliceosome, to induce the G2/M cell cycle arrest, apoptosis, and p73 splicing in cervical cancer cells [103]. Other small molecules evaluated in cervical cancer include RI-1, a RAD51 inhibitor [104]. Modified gene expression is a central characteristic of cancer cells such as the altered expression of RAD51 mRNA in cervical cancer cells compared with healthy cells [75]. RI-1 promotes cell cycle arrest from G0/G1 to S phase and inhibits the RAD51-induced cell proliferation in cervical cancer cells [104]. These results indicate the potential of pharmacological agents to regulate alternative splicing in cervical cancer and their therapeutic potential. 
Inhibiting splicing factors can evoke a tumour suppressive function. For instance, blocking the function of SRSF1 may contribute to apoptotic activity. Cervical cancer cells treated with an AURKA kinase inhibitor, such as the pharmacological agent VX-680, downregulate the post-transcriptional expression levels of SRSF1 [105]. AURKA kinases, part of the aurora family of proteins, are cell division regulators. Dysregulation of these proteins leads to uncontrolled cell division and proliferation, resulting in malignancy [42]. Cervical cancer cells treated with VX-680 promote aberrant alternative splicing of apoptotic regulating genes, Bcl-x and Mcl-1, and inhibit the anti-apoptotic function of SRSF1, leading to apoptosis [105]. Silencing of SRSF1, therefore, signifies a novel therapeutic target for cervical cancer.

\section{Conclusions}

The mortality associated with cervical cancer is increasing at an alarming rate. The development of cervical cancer is largely influenced by HPV infections in low- and middleincome countries that add to this encumbrance. Vaccination programs addressing HPV have been successful in lowering HPV infections in high-risk women. Moreover, screening and prevention programs are useful in early detection and treatment. In addition to HPV infections, molecular alterations at the RNA level contribute to cervical carcinoma. These include modifications in cellular alternative splicing induced by HPV. RBPs like SRs and hnRNPs are essential in maintaining the stability and packing of mRNAs, as well as transport to the cytoplasm for further processing. These processes are intricately balanced by several splicing factors and proteins to ensure accurate alternative splicing. Despite the stringent regulation, SR proteins and hnRNPs are often dysregulated in cervical cancer and lead to aberrant alternative splicing of many important cancer-related genes, including therapy resistance. For these reasons, SR proteins and hnRNPs are ideal candidates for drug targets. Hence, identifying biomarkers crucial to the development of cervical malignancy, its pathogenesis, and splice variants that are highly expressed in cervical cancer will be beneficial in developing novel therapeutic targets, especially in low- and middle-income countries where the burden of cervical cancer is rapidly increasing.

Author Contributions: F.Z.F. was involved in writing original draft preparation and editing; S.B. was involved in review and editing; A.C. was involved in final review and editing; A.M.K. was involved in final review and editing; Z.D. conceived the idea, funding acquisition, supervision, and involved in review and editing. All authors have read and agreed to the published version of the manuscript.

Funding: This research was funded by the Medical Research Council of South Africa, grant number: 23108.

Institutional Review Board Statement: Not applicable.

Informed Consent Statement: Not applicable.

Data Availability Statement: Not applicable.

Acknowledgments: We would like to thank the Medical Research Council of South Africa (SAMRC) and the University of Pretoria for funding this research.

Conflicts of Interest: The authors declare no conflict of interest. The funders had no role in the design of the study; in the collection, analyses, or interpretation of data; in the writing of the manuscript; or in the decision to publish the results.

\section{References}

1. Arbyn, M.; Weiderpass, E.; Bruni, L.; de Sanjosé, S.; Saraiya, M.; Ferlay, J.; Bray, F. Estimates of incidence and mortality of cervical cancer in 2018: A worldwide analysis. Lancet Glob. Health 2020, 8, e191-e203. [CrossRef]

2. IARC. Cancer Today. Available online: https://gco.iarc.fr/today/online-analysis-map?v=2018\&mode=cancer\&mode population $=$ continents $\&$ population $=900 \&$ populations $=900 \&$ key $=$ asr $\&$ sex $=2 \&$ cancer $=39 \&$ type $=1 \&$ statistic $=5 \&$ prevalence $=0 \&$ population_group $=0 \& a g e s \_g r o u p ~ \% 5 \mathrm{~B} \% 5 \mathrm{D}=0 \&$ ages_group $\% 5 \mathrm{~B} \% 5 \mathrm{D}=17 \& \mathrm{nb} \_$items $=10 \&$ group_cancer $=1 \&$ include_nmsc $=1 \&$ include_nmsc_other $=1 \&$ projection $=$ natural-earth\&color_palette $=$ default $\&$ map_scale $=q u a n t i l e \& m a p \_n b \_c o l o r s=5 \& c o n t i n e n t=$ $0 \&$ rotate $=\% 255 \mathrm{~B} 10 \% 252 \mathrm{C} 0 \% 255 \mathrm{D}$ (accessed on 20 October 2020). 
3. Bray, F.; Ferlay, J.; Soerjomataram, I.; Siegel, R.L.; Torre, L.A.; Jemal, A. Global cancer statistics 2018: GLOBOCAN estimates of incidence and mortality worldwide for 36 cancers in 185 countries. CA Cancer J. Clin. 2018, 68, 394-424. [CrossRef] [PubMed]

4. Ferlay, J.; Soerjomataram, I.; Dikshit, R.; Eser, S.; Mathers, C.; Rebelo, M.; Parkin, D.M.; Forman, D.; Bray, F. Cancer incidence and mortality worldwide: Sources, methods and major patterns in GLOBOCAN 2012. Int. J. Cancer 2015, 136, E359-E386. [CrossRef] [PubMed]

5. Lax, S. Histopathology of cervical precursor lesions and cancer. Acta Dermatovenerol. Alp. Pannon. Adriat. 2011, 20, 125-133.

6. Chiang, Y.-C.; Chen, Y.-Y.; Hsieh, S.-F.; Chiang, C.-J.; You, S.-L.; Cheng, W.-F.; Lai, M.-S.; Chen, C.-A. Screening frequency and histologic type influence the efficacy of cervical cancer screening: A nationwide cohort study. Taiwan. J. Obstet. Gynecol. 2017, 56, 442-448. [CrossRef] [PubMed]

7. Safaeian, M.; Solomon, D.; Castle, P.E. Cervical cancer prevention-Cervical screening: Science in evolution. Obstet. Gynecol. Clin. N. Am. 2007, 34, 739-760. [CrossRef]

8. Momenimovahed, Z.; Salehiniya, H. Incidence, mortality and risk factors of cervical cancer in the world. Biomed. Res. Ther. 2017, 4, 1795-1811. [CrossRef]

9. Kabekkodu, S.P.; Chakrabarty, S.; Ghosh, S.; Brand, A.; Satyamoorthy, K. Epigenomics, Pharmacoepigenomics, and Personalized Medicine in Cervical Cancer. Public Health Genom. 2017, 20, 100-115. [CrossRef]

10. Akinlotan, M.; Bolin, J.N.; Helduser, J.; Ojinnaka, C.; Lichorad, A.; McClellan, D. Cervical Cancer Screening Barriers and Risk Factor Knowledge Among Uninsured Women. J. Community Health 2017, 42, 770-778. [CrossRef]

11. Chan, C.K.; Aimagambetova, G.; Ukybassova, T.; Kongrtay, K.; Azizan, A. Human Papillomavirus Infection and Cervical Cancer: Epidemiology, Screening, and Vaccination-Review of Current Perspectives. J. Oncol. 2019, 2019, 3257939. [CrossRef]

12. Sankaranarayanan, R. HPV vaccination: The most pragmatic cervical cancer primary prevention strategy. Int. J. Gynaecol. Obstet. 2015, 131 (Suppl. 1), S33-S35. [CrossRef] [PubMed]

13. Joura, E.A.; Giuliano, A.R.; Iversen, O.E.; Bouchard, C.; Mao, C.; Mehlsen, J.; Moreira, E.D., Jr.; Ngan, Y.; Petersen, L.K.; LazcanoPonce, E.; et al. A 9-valent HPV vaccine against infection and intraepithelial neoplasia in women. N. Engl. J. Med. 2015, 372, 711-723. [CrossRef] [PubMed]

14. Wu, K.; Yi, Y.; Liu, F.; Wu, W.; Chen, Y.; Zhang, W. Identification of key pathways and genes in the progression of cervical cancer using bioinformatics analysis. Oncol. Lett. 2018, 16, 1003-1009. [CrossRef] [PubMed]

15. Sharma, G.; Dua, P.; Agarwal, S.M. A Comprehensive Review of Dysregulated miRNAs Involved in Cervical Cancer. Curr. Genom. 2014, 15, 310-323. [CrossRef]

16. Campos-Parra, A.D.; Padua-Bracho, A.; Pedroza-Torres, A.; Figueroa-González, G.; Fernández-Retana, J.; Millan-Catalan, O.; Peralta-Zaragoza, O.; Cantú de León, D.; Herrera, L.A.; Pérez-Plasencia, C. Comprehensive transcriptome analysis identifies pathways with therapeutic potential in locally advanced cervical cancer. Gynecol. Oncol. 2016, 143, 406-413. [CrossRef]

17. Lin, M.; Ye, M.; Zhou, J.; Wang, Z.P.; Zhu, X. Recent Advances on the Molecular Mechanism of Cervical Carcinogenesis Based on Systems Biology Technologies. Comput. Struct. Biotechnol. J. 2019, 17, 241-250. [CrossRef]

18. Graham, S.V.; Faizo, A.A.A. Control of human papillomavirus gene expression by alternative splicing. Virus Res. 2017, 231, 83-95. [CrossRef]

19. Qi, F.; Li, Y.; Yang, X.; Wu, Y.-P.; Lin, L.-J.; Liu, X.-M. Significance of alternative splicing in cancer cells. Chin. Med. J. 2020, 133, 221-228. [CrossRef]

20. Zheng, Y.; Jönsson, J.; Hao, C.; Shoja Chaghervand, S.; Cui, X.; Kajitani, N.; Gong, L.; Wu, C.; Schwartz, S. Heterogeneous Nuclear Ribonucleoprotein A1 (hnRNP A1) and hnRNP A2 Inhibit Splicing to Human Papillomavirus 16 Splice Site SA409 through a UAG-Containing Sequence in the E7 Coding Region. J. Virol. 2020, 94, e01509-e01520. [CrossRef]

21. Mole, S.; Faizo, A.A.A.; Hernandez-Lopez, H.; Griffiths, M.; Stevenson, A.; Roberts, S.; Graham, S.V. Human papillomavirus type 16 infection activates the host serine arginine protein kinase 1 (SRPK1)—Splicing factor axis. J. Gen. Virol. 2020, 101, 523-532. [CrossRef]

22. Dong, M.; Dong, Z.; Zhu, X.; Zhang, Y.; Song, L. Long non-coding RNA MIR205HG regulates KRT17 and tumor processes in cervical cancer via interaction with SRSF1. Exp. Mol. Pathol. 2019, 111, 104322. [CrossRef] [PubMed]

23. Kim, Y.-J.; Kim, B.-R.; Ryu, J.-S.; Lee, G.-O.; Kim, H.-R.; Choi, K.-H.; Ryu, J.-W.; Na, K.-S.; Park, M.-C.; So, H.-S.; et al. HNRNPA1, a Splicing Regulator, Is an Effective Target Protein for Cervical Cancer Detection: Comparison With Conventional Tumor Markers. Int. J. Gynecol. Cancer 2017, 27, 326. [CrossRef] [PubMed]

24. Singh, B.; Eyras, E. The role of alternative splicing in cancer. Transcription 2017, 8, 91-98. [CrossRef] [PubMed]

25. Mthembu, N.N.; Mbita, Z.; Hull, R.; Dlamini, Z. Abnormalities in alternative splicing of angiogenesis-related genes and their role in HIV-related cancers. HIV AIDS (Auckl) 2017, 9, 77-93. [CrossRef]

26. Urbanski, L.M.; Leclair, N.; Anczuków, O. Alternative-splicing defects in cancer: Splicing regulators and their downstream targets, guiding the way to novel cancer therapeutics. J. Virol. 2018, 9, e1476. [CrossRef]

27. Bergsma, A.J.; van der Wal, E.; Broeders, M.; van der Ploeg, A.T.; Pim Pijnappel, W.W.M. Alternative Splicing in Genetic Diseases: Improved Diagnosis and Novel Treatment Options. In International Review of Cell and Molecular Biology; Loos, F., Ed.; Academic Press: Cambridge, MA, USA, 2018; Volume 335, pp. 85-141.

28. Guo, P.; Wang, D.; Wu, J.; Yang, J.; Ren, T.; Zhu, B.; Xiang, Y. The landscape of alternative splicing in cervical squamous cell carcinoma. Oncotargets Ther. 2014, 8, 73-79. [CrossRef] 
29. Liu, F.; Dai, M.; Xu, Q.; Zhu, X.; Zhou, Y.; Jiang, S.; Wang, Y.; Ai, Z.; Ma, L.; Zhang, Y.; et al. SRSF10-mediated IL1RAP alternative splicing regulates cervical cancer oncogenesis via mIL1RAP-NF-kB-CD47 axis. Oncogene 2018, 37, 2394-2409. [CrossRef]

30. Ouyang, D.; Yang, P.; Cai, J.; Sun, S.; Wang, Z. Comprehensive analysis of prognostic alternative splicing signature in cervical cancer. Cancer Cell Int. 2020, 20, 221. [CrossRef]

31. Cerasuolo, A.; Buonaguro, L.; Buonaguro, F.M.; Tornesello, M.L. The Role of RNA Splicing Factors in Cancer: Regulation of Viral and Human Gene Expression in Human Papillomavirus-Related Cervical Cancer. Front. Cell Dev. Biol. 2020, 8. [CrossRef]

32. Chen, J.; Weiss, W.A. Alternative splicing in cancer: Implications for biology and therapy. Oncogene 2015, 34, 1-14. [CrossRef]

33. Iñiguez, L.P.; Hernández, G. The Evolutionary Relationship between Alternative Splicing and Gene Duplication. Front. Genet. 2017, 8, 8. [CrossRef] [PubMed]

34. Shkreta, L.; Cloutier, A.; Toutant, J.; Rendos, H.V.; Chabot, B. Regulation of alternative splicing and the case of Bcl-x. Pak. J. Biochem. Mol. Biol. 2015, 48, 27-38.

35. Makhafola, T.J.; Mbele, M.; Yacqub-Usman, K.; Hendren, A.; Haigh, D.B.; Blackley, Z.; Meyer, M.; Mongan, N.P.; Bates, D.O.; Dlamini, Z. Apoptosis in Cancer Cells Is Induced by Alternative Splicing of hnRNPA2/B1 Through Splicing of Bcl-x, a Mechanism that Can Be Stimulated by an Extract of the South African Medicinal Plant, Cotyledon orbiculata. Front. Oncol. 2020, 10, 10. [CrossRef] [PubMed]

36. Li, W.; Qi, Y.; Cui, X.; Huo, Q.; Zhu, L.; Zhang, A.; Tan, M.; Hong, Q.; Yang, Y.; Zhang, H.; et al. Characteristic of HPV Integration in the Genome and Transcriptome of Cervical Cancer Tissues. BioMed Res. Int. 2018, 2018, 6242173. [CrossRef] [PubMed]

37. Burd, E.M. Human papillomavirus and cervical cancer. Clin. Microbiol. Rev. 2003, 16, 1-17. [CrossRef]

38. Yim, E.-K.; Park, J.-S. Biomarkers in cervical cancer. Biomark Insights 2007, 1, 215-225. [CrossRef]

39. Sahasrabuddhe, V.V.; Luhn, P.; Wentzensen, N. Human papillomavirus and cervical cancer: Biomarkers for improved prevention efforts. Future Microbiol. 2011, 6, 1083-1098. [CrossRef]

40. Twu, N.F.; Yuan, C.C.; Yen, M.S.; Lai, C.R.; Chao, K.C.; Wang, P.H.; Wu, H.H.; Chen, Y.J. Expression of Aurora kinase A and B in normal and malignant cervical tissue: High Aurora A kinase expression in squamous cervical cancer. Eur. J. Obstet. Gynecol. Reprod. Biol. 2009, 142, 57-63. [CrossRef]

41. van Dam, P.A.; Rolfo, C.; Ruiz, R.; Pauwels, P.; Van Berckelaer, C.; Trinh, X.B.; Ferri Gandia, J.; Bogers, J.P.; Van Laere, S. Potential new biomarkers for squamous carcinoma of the uterine cervix. J. ESMO Open 2018, 3, e000352. [CrossRef]

42. Suman, S.; Mishra, A. Network analysis revealed aurora kinase dysregulation in five gynecological types of cancer. Oncol. Lett. 2018, 15, 1125-1132. [CrossRef]

43. Ahmed, S.; Obaseki, D.; Mayun, A.; Mohammed, A.; Rafindadi, A.; Abdul, M. The role of biomarkers (p16 ${ }^{\mathrm{INK} 4 \mathrm{a}}$ and Ki-67) in cervical cancer screening: An appraisal. Ann. Trop. Pathol. 2017, 8, 1-4. [CrossRef]

44. Cheah, P.L.; Looi, L.M.; Mun, K.S.; Abdoul Rahman, N.; Teoh, K.H. Implications of continued upregulation of p16(INK4a) through the evolution from high-grade squamous intraepithelial lesion to invasive squamous carcinoma of the cervix. Malays. J. Pathol. 2011, 33, 83-87. [PubMed]

45. von Knebel Doeberitz, M.; Reuschenbach, M.; Schmidt, D.; Bergeron, C. Biomarkers for cervical cancer screening: The role of p16(INK4a) to highlight transforming HPV infections. Expert Rev. Proteom. 2012, 9, 149-163. [CrossRef] [PubMed]

46. Shi, Q.; Xu, L.; Yang, R.; Meng, Y.; Qiu, L. Ki-67 and P16 proteins in cervical cancer and precancerous lesions of young women and the diagnostic value for cervical cancer and precancerous lesions. Oncol. Lett. 2019, 18, 1351-1355. [CrossRef] [PubMed]

47. Tornesello, M.L.; Buonaguro, L.; Giorgi-Rossi, P.; Buonaguro, F.M. Viral and Cellular Biomarkers in the Diagnosis of Cervical Intraepithelial Neoplasia and Cancer. BioMed Res. Int. 2013, 2013, 519619. [CrossRef]

48. Organista-Nava, J.; Gómez-Gómez, Y.; Garibay-Cerdenares, O.L.; Leyva-Vázquez, M.A.; Illades-Aguiar, B. Cervical cancer stem cell-associated genes: Prognostic implications in cervical cancer (Review). Oncol. Lett. 2019, 18, 7-14. [CrossRef]

49. Gong, P.; Wang, Y.; Gao, Y.; Gao, M.; Liu, L.; Qu, P.; Jin, X.; Gao, Q. Msi1 promotes tumor progression by epithelial-to-mesenchymal transition in cervical cancer. Hum. Pathol. 2017, 65, 53-61. [CrossRef]

50. Liu, X.; Yang, W.T.; Zheng, P.S. Msi1 promotes tumor growth and cell proliferation by targeting cell cycle checkpoint proteins p21, p27 and p53 in cervical carcinomas. Oncotarget 2014, 5, 10870-10885. [CrossRef]

51. Hou, T.; Zhang, W.; Tong, C.; Kazobinka, G.; Huang, X.; Huang, Y.; Zhang, Y. Putative stem cell markers in cervical squamous cell carcinoma are correlated with poor clinical outcome. BMC Cancer 2015, 15, 785. [CrossRef]

52. Tulake, W.; Yuemaier, R.; Sheng, L.; Ru, M.; Lidifu, D.; Abudula, A. Upregulation of stem cell markers ALDH1A1 and OCT4 as potential biomarkers for the early detection of cervical carcinoma. Oncol. Lett. 2018, 16, 5525-5534. [CrossRef]

53. Yadav, S.; Verma, A.; Sarin, N.; Singh, S. Expression of epidermal growth factor receptor in squamous cell carcinoma of uterine cervix. Clin. Cancer Investig. J. 2019, 8, 227-231. [CrossRef]

54. Chen, Q.; Huang, Y.; Shao, L.; Han-Zhang, H.; Yang, F.; Wang, Y.; Liu, J.; Gan, J. An EGFR-Amplified Cervical Squamous Cell Carcinoma Patient with Pulmonary Metastasis Benefits from Afatinib: A Case Report. Oncotargets Ther. 2020, 13, 1845-1849. [CrossRef] [PubMed]

55. Kim, B.W.; Cho, H.; Choi, C.H.; Ylaya, K.; Chung, J.-Y.; Kim, J.-H.; Hewitt, S.M. Clinical significance of OCT4 and SOX2 protein expression in cervical cancer. BMC Cancer 2015, 15, 1015. [CrossRef] [PubMed]

56. Ammothumkandy, A.; Maliekal, T.T.; Bose, M.V.; Rajkumar, T.; Shirley, S.; Thejaswini, B.; Giri, V.G.; Krishna, S. CD66 and CD49f expressing cells are associated with distinct neoplastic phenotypes and progression in human cervical cancer. Eur. J. Cancer 2016, 60, 166-178. [CrossRef] 
57. Javed, S.; Sharma, B.K.; Sood, S.; Sharma, S.; Bagga, R.; Bhattacharyya, S.; Rayat, C.S.; Dhaliwal, L.; Srinivasan, R. Significance of CD133 positive cells in four novel HPV-16 positive cervical cancer-derived cell lines and biopsies of invasive cervical cancer. BMC Cancer 2018, 18, 357. [CrossRef]

58. Gutiérrez-Hoya, A.; Zerecero-Carreón, O.; Valle-Mendiola, A.; Moreno-Lafont, M.; López-Santiago, R.; Weiss-Steider, B.; SotoCruz, I. Cervical Cancer Cells Express Markers Associated with Immunosurveillance. J. Immunol. Res. 2019, $2019,1242979$. [CrossRef]

59. Kori, M.; Yalcin Arga, K. Potential biomarkers and therapeutic targets in cervical cancer: Insights from the meta-analysis of transcriptomics data within network biomedicine perspective. PLoS ONE 2018, 13, e0200717. [CrossRef]

60. Wang, Z.; Burge, C.B. Splicing regulation: From a parts list of regulatory elements to an integrated splicing code. RNA 2008, 14, 802-813. [CrossRef]

61. Lam, B.J.; Hertel, K.J. A general role for splicing enhancers in exon definition. RNA 2002, 8, 1233-1241. [CrossRef]

62. Long, J.C.; Caceres, J.F. The SR protein family of splicing factors: Master regulators of gene expression. Biochem. J. 2008, 417, 15-27. [CrossRef]

63. Howard, J.M.; Sanford, J.R. The RNAissance family: SR proteins as multifaceted regulators of gene expression. Wiley Interdiscip. Rev. RNA 2015, 6, 93-110. [CrossRef] [PubMed]

64. Zhou, Z.; Fu, X.-D. Regulation of splicing by SR proteins and SR protein-specific kinases. Chromosoma 2013, 122, 191-207. [CrossRef] [PubMed]

65. Somberg, M. Cellular and Viral Factors that Control Human Papillomavirus Type 16 Late Gene Expression. Ph.D. Thesis, Comprehensive Summary. Acta Universitatis Upsaliensis, Uppsala, Sweden, 2011.

66. Twyffels, L.; Gueydan, C.; Kruys, V. Shuttling SR proteins: More than splicing factors. FEBS J. 2011, 278, 3246-3255. [CrossRef] [PubMed]

67. Prescott, E.L.; Brimacombe, C.L.; Hartley, M.; Bell, I.; Graham, S.; Roberts, S. Human papillomavirus type 1 E1^E4 protein is a potent inhibitor of the serine-arginine (SR) protein kinase SRPK1 and inhibits phosphorylation of host SR proteins and of the viral transcription and replication regulator E2. J. Virol. 2014, 88, 12599-12611. [CrossRef] [PubMed]

68. Karni, R.; de Stanchina, E.; Lowe, S.W.; Sinha, R.; Mu, D.; Krainer, A.R. The gene encoding the splicing factor SF2/ASF is a proto-oncogene. Nat. Struct. Mol. Biol. 2007, 14, 185-193. [CrossRef] [PubMed]

69. Jia, R.; Li, C.; McCoy, J.P.; Deng, C.-X.; Zheng, Z.-M. SRp20 is a proto-oncogene critical for cell proliferation and tumor induction and maintenance. Int. J. Biol. Sci. 2010, 6, 806-826. [CrossRef] [PubMed]

70. Ajiro, M.; Jia, R.; Yang, Y.; Zhu, J.; Zheng, Z.-M. A genome landscape of SRSF3-regulated splicing events and gene expression in human osteosarcoma U2OS cells. Nucleic Acids Res. 2016, 44, 1854-1870. [CrossRef]

71. Jia, R.; Ajiro, M.; Yu, L.; McCoy, P., Jr.; Zheng, Z.M. Oncogenic splicing factor SRSF3 regulates ILF3 alternative splicing to promote cancer cell proliferation and transformation. RNA 2019, 25, 630-644. [CrossRef]

72. Jia, R.; Liu, X.; Tao, M.; Kruhlak, M.; Guo, M.; Meyers, C.; Baker, C.C.; Zheng, Z.-M. Control of the Papillomavirus Early-to-Late Switch by Differentially Expressed SRp20. J. Virol. 2009, 83, 167-180. [CrossRef]

73. Ajiro, M.; Tang, S.; Doorbar, J.; Zheng, Z.-M. Serine/Arginine-Rich Splicing Factor 3 and Heterogeneous Nuclear Ribonucleoprotein A1 Regulate Alternative RNA Splicing and Gene Expression of Human Papillomavirus 18 through Two Functionally Distinguishable cis Elements. J. Virol. 2016, 90, 9138-9152. [CrossRef]

74. Wieringa, H.W.; van der Zee, A.G.J.; de Vries, E.G.E.; van Vugt, M.A.T.M. Breaking the DNA damage response to improve cervical cancer treatment. Cancer Treat. Rev. 2016, 42, 30-40. [CrossRef] [PubMed]

75. Leonardi, S.; Buttarelli, M.; De Stefano, I.; Ferrandina, G.; Petrillo, M.; Babini, G.; Scambia, G.; Marino, C.; Mancuso, M.; Gallo, D. The relevance of prelamin A and RAD51 as molecular biomarkers in cervical cancer. Oncotarget 2017, 8, 94247-94258. [CrossRef] [PubMed]

76. Banerjee, N.S.; Moore, D.; Parker, C.J.; Broker, T.R.; Chow, L.T. Targeting DNA Damage Response as a Strategy to Treat HPV Infections. Int. J. Mol. Sci. 2019, 20, 5455. [CrossRef] [PubMed]

77. Sample, K.M. DNA repair gene expression is associated with differential prognosis between HPV16 and HPV18 positive cervical cancer patients following radiation therapy. Sci. Rep. 2020, 10, 2774. [CrossRef]

78. Yang, X.; Zhan, P.; Feng, S.; Ji, H.; Tian, W.; Wang, M.; Cheng, C.; Song, B. SRSF6 regulates alternative splicing of genes involved in DNA damage response and DNA repair in HeLa cells. Oncol. Rep. 2020, 44, 1851-1862. [CrossRef]

79. Geuens, T.; Bouhy, D.; Timmerman, V. The hnRNP family: Insights into their role in health and disease. Hum. Genet. 2016, 135, 851-867. [CrossRef]

80. Chen, Q.; Jin, M.; Zhu, J.; Xiao, Q.; Zhang, L. Functions of Heterogeneous Nuclear Ribonucleoproteins in Stem Cell Potency and Differentiation. BioMed Res. Int. 2013, 2013, 623978. [CrossRef]

81. Shao, X.-Y.; Dong, J.; Zhang, H.; Wu, Y.-S.; Zheng, L. Prognostic Value and Potential Role of Alternative mRNA Splicing Events in Cervical Cancer. Front. Genet. 2020, 11, 11. [CrossRef]

82. Erdem, M.; Özgül, I.; Erson-Bensan, A.E. HNRNPA1 (Heterogeneous Nuclear Ribonucleoprotein A1). Atlas Genet. Cytogenet. Oncol. Haematol. 2019, 23, 137-142. [CrossRef]

83. Roman, A.; Munger, K. The papillomavirus E7 proteins. Virology 2013, 445, 138-168. [CrossRef]

84. Vande Pol, S.B.; Klingelhutz, A.J. Papillomavirus E6 oncoproteins. Virology 2013, 445, 115-137. [CrossRef] [PubMed] 
85. Narisawa-Saito, M.; Kiyono, T. Basic mechanisms of high-risk human papillomavirus-induced carcinogenesis: Roles of E6 and E7 proteins. Cancer Sci. 2007, 98, 1505-1511. [CrossRef] [PubMed]

86. Dalenc, F.; Drouet, J.; Ader, I.; Delmas, C.; Rochaix, P.; Favre, G.; Cohen-Jonathan, E.; Toulas, C. Increased expression of a $\mathrm{COOH}$-truncated nucleophosmin resulting from alternative splicing is associated with cellular resistance to ionizing radiation in HeLa cells. Int. J. Cancer 2002, 100, 662-668. [CrossRef]

87. Zhu, W.; Pan, X.; Yang, Z.; Xing, P.; Zhang, Y.; Li, F.; Lu, X. Expression and prognostic significance of TAp73 and $\Delta$ Np73 in FIGO stage I-II cervical squamous cell carcinoma. Oncol. Lett. 2015, 9, 2090-2094. [CrossRef] [PubMed]

88. Siegfried, Z.; Karni, R. The role of alternative splicing in cancer drug resistance. Curr. Opin. Genet. Dev. 2018, 48, 16-21. [CrossRef]

89. Sciarrillo, R.; Wojtuszkiewicz, A.; Assaraf, Y.G.; Jansen, G.; Kaspers, G.J.L.; Giovannetti, E.; Cloos, J. The role of alternative splicing in cancer: From oncogenesis to drug resistance. Drug Resist. Updates 2020, 53, 100728. [CrossRef]

90. Box, J.K.; Paquet, N.; Adams, M.N.; Boucher, D.; Bolderson, E.; O’Byrne, K.J.; Richard, D.J. Nucleophosmin: From structure and function to disease development. BMC Mol. Biol. 2016, 17, 19. [CrossRef]

91. Di, C.X.; Yang, L.N.; Zhang, H.; An, L.Z.; Zhang, X.; Ma, X.F.; Sun, C.; Wang, X.H.; Yang, R.; Wu, Z.H.; et al. Effects of carbon-ion beam or X-ray irradiation on anti-apoptosis $\Delta$ Np73 expression in HeLa cells. Gene 2013, 515, 208-213. [CrossRef]

92. Ishimoto, O.; Kawahara, C.; Enjo, K.; Obinata, M.; Nukiwa, T.; Ikawa, S. Possible Oncogenic Potential of $\Delta$ Np73: A newly identified isoform of human p73. Cancer Res. 2002, 62, 636-641.

93. Liang, X.; Chen, B.; Zhong, J. Association of P73 polymorphisms with susceptibilities of cervical carcinoma: A meta-analysis. Oncotarget 2017, 8, 57409-57413. [CrossRef]

94. Ye, H.; Guo, X. TP73 is a credible biomarker for predicting clinical progression and prognosis in cervical cancer patients. Biosci. Rep. 2019, 39, BSR20190095. [CrossRef] [PubMed]

95. Liu, S.S.; Chan, K.Y.-K.; Leung, R.C.-Y.; Law, H.K.-W.; Leung, T.-W.; Ngan, H.Y.-S. Enhancement of the radiosensitivity of cervical cancer cells by overexpressing p73 $\alpha$. J. Mol. Cancer Ther. 2006, 5, 1209-1215. [CrossRef] [PubMed]

96. Kumar, L.; Harish, P.; Malik, P.S.; Khurana, S. Chemotherapy and targeted therapy in the management of cervical cancer. Curr. Probl. Cancer 2018, 42, 120-128. [CrossRef] [PubMed]

97. Ji, H.; Li, B.; Zhang, S.; He, Z.; Zhou, Y.; Ouyang, L. Crk-like adapter protein is overexpressed in cervical carcinoma, facilitates proliferation, invasion and chemoresistance, and regulates Src and Akt signaling. Oncol. Lett. 2016, 12, 3811-3817. [CrossRef] [PubMed]

98. Song, Q.; Yi, F.; Zhang, Y.; Jun Li, D.K.; Wei, Y.; Yu, H.; Zhang, Y. CRKL regulates alternative splicing of cancer-related genes in cervical cancer samples and HeLa cell. BMC Cancer 2019, 19, 499. [CrossRef] [PubMed]

99. Wang, Y.; Liu, L.; Chen, Z. Transcriptome profiling of cervical cancer cells acquired resistance to cisplatin by deep sequencing. Artif. Cells Nanomed. Biotechnol. 2019, 47, 2820-2829. [CrossRef]

100. Ye, G.; Lu, Q.; Zhao, W.; Du, D.; Jin, L.; Liu, Y. Fucoxanthin induces apoptosis in human cervical cancer cell line HeLa via PI3K/Akt pathway. Tumor Biol. 2014, 35, 11261-11267. [CrossRef]

101. Lu, G.Y.; Huang, S.M.; Liu, S.T.; Liu, P.Y.; Chou, W.Y.; Lin, W.S. Caffeine induces tumor cytotoxicity via the regulation of alternative splicing in subsets of cancer-associated genes. Int. J. Biochem. Cell Biol. 2014, 47, 83-92. [CrossRef]

102. Di, C.; Syafrizayanti; Zhang, Q.; Chen, Y.; Wang, Y.; Zhang, X.; Liu, Y.; Sun, C.; Zhang, H.; Hoheisel, J.D. Function, clinical application, and strategies of Pre-mRNA splicing in cancer. Cell Death Differ. 2019, 26, 1181-1194. [CrossRef]

103. Zhang, Q.; Di, C.; Yan, J.; Wang, F.; Qu, T.; Wang, Y.; Chen, Y.; Zhang, X.; Liu, Y.; Yang, H.; et al. Inhibition of SF3b1 by pladienolide $\mathrm{B}$ evokes cycle arrest, apoptosis induction and p73 splicing in human cervical carcinoma cells. Artif. Cells Nanomed. Biotechnol. 2019, 47, 1273-1280. [CrossRef]

104. Chen, Q.; Cai, D.; Li, M.; Wu, X. The homologous recombination protein RAD51 is a promising therapeutic target for cervical carcinoma. Oncol. Rep. 2017, 38, 767-774. [CrossRef] [PubMed]

105. Kędzierska, H.; Piekiełko-Witkowska, A. Splicing factors of SR and hnRNP families as regulators of apoptosis in cancer. Cancer Lett. 2017, 396, 53-65. [CrossRef] [PubMed] 